\title{
Characterization of aroma-active compounds, sensory properties, and proteolysis in Ezine cheese
}

\author{
Y. Karagul Yuceer, ${ }^{* 1}$ B. Tuncel, ${ }^{*}$ O. Guneser, ${ }^{*}$ B. Engin, ${ }^{*}$ M. Isleten, ${ }^{*}$ K. Yasar, ${ }^{*}$ and M. Mendes† \\ ${ }^{*}$ Faculty of Engineering-Architecture, Department of Food Engineering, and \\ †Agricultural Faculty, Animal Science Department, Canakkale Onsekiz Mart University, Terzioglu Campus, 17020 Canakkale, Turkey
}

\begin{abstract}
Ezine cheese is a white pickled cheese ripened in tinplate containers for at least 8 mo. A mixture of milk from goat, sheep, and cow is used to make Ezine cheese. Ezine cheese has geographical indication status. The purposes of this study were to determine and compare the changes in basic composition, aroma, and sensory characteristics, and proteolytic activity of Ezine cheese stored in tinplate containers and plastic vacuum packages during storage. Aroma-active compounds were determined by thermal desorption gas chromatography olfactometry. To evaluate the proteolytic activity, casein and nitrogen fractions were determined. The results indicated that compounds identified at high intensities were dimethyl sulfide, ethyl butyrate, hexanal, ethyl pentanoate, (Z)-4-heptenal, 1-octen-3-one, acetic acid, butyric acid, and $p$-cresol. Characteristic descriptive terms were cooked, whey, creamy, animal-like, sour, and salty. The level of proteolysis increased in Ezine cheese during storage. Ezine cheese can be ripened in smallsize packaging after 3 mo of storage. Approximately 6 mo is sufficient to produce the characteristic properties of Ezine cheese.
\end{abstract}

Key words: Ezine cheese, aroma, proteolysis, packaging type

\section{INTRODUCTION}

Ezine cheese is a full-fat, white pickled cheese variety. Ezine cheese is produced from the mixture of goat milk (at least 40\%), sheep milk (45-55\%), and cow milk (at most 15\%) provided from the towns and villages located in the north and west of the Mount Ida region of Turkey. Ezine cheese has geographical indication (TPE, 2006) status. In general, the cheese is ripened in tinplate containers for at least 8 mo. Cheese milk is

Received February 12, 2009.

Accepted May 29, 2009.

${ }^{1}$ Corresponding author: yoncayuceer@comu.edu.tr pasteurized and no starter culture is used for production of the cheese.

Cheese flavor originates from enzymatic, chemical, or microbial transformations of protein, fat, lactose, and citrate in milk (Law, 1984; Fox et al., 1995). Lactose, lipid, and protein catabolisms are main sources of generation of aroma compounds in cheese. These pathways are activated by endogenous enzymes in milk, coagulating enzymes, and microbial enzymes used to manufacture or ripen cheese.

Massouras et al. (2006) determined volatile flavor compounds of Teleme cheese made from sheep and goat milk by using the headspace technique. Teleme cheese is also a white pickled cheese variety and starter culture is used to produce this cheese. Teleme cheese is salty and sour. It can be produced from sheep, goat, cow milk, or any mixture thereof (Massouras et al., 2006). In this study, a total of 21 major compounds were identified, including aldehydes, alcohols, ketones, and acids.

Proteolysis is the major biochemical process in the development of cheese flavor. Degradation of casein by milk coagulating enzymes and proteinases and peptidases from lactic acid bacteria leads to the generation of peptides and free amino acids. Amino acids do not contribute to the flavor, but they are precursors of the aromatics. Degradation of amino acids to alcohols, aldehydes, acids, esters, and sulfur compounds is required for development of characteristic flavor in certain types of cheeses (Kranenburg et al., 2002). Amino acid catabolites by lactic acid bacteria isolated from Cheddar cheese were reported by Singh et al. (2003). For example, methionine/cysteine is a precursor of methanethiol, which has a cabbage-like aroma note. Methionine is also precursor of methional with boiled potato aroma. In addition, $p$-cresol is produced by degradation of tyrosine (Singh et al., 2003). Acetalydehyde is a major aroma compound of fermented dairy foods and threonine aldolase converts treonine into acetaldehyde (Ott et al., 2000).

Proteolytic activity of cheese is caused by enzymes from coagulant, milk, and bacteria (starter, nonstarter, or secondary starter) (Fox, 1989). Hayaloglu et al. (2005) investigated the effect of certain starter cultures 
on proteolytic profile and ripening characteristics of Turkish White brined cheese during a 3-mo ripening period. The results of that study showed that cheeses manufactured with a starter culture had a higher concentration of soluble N. Urea PAGE patterns also showed that hydrolysis of caseins accelerated during ripening. Specifically, $\alpha_{\mathrm{S} 1}$-casein was extensively degraded after $30 \mathrm{~d}$ of storage. However, $\beta$-casein was degraded slowly during maturation.

Ezine cheese has its own characteristic taste and aroma different from other white pickled cheeses. No starter culture is used to produce this cheese. It is produced in a specific region and widely consumed in Turkey. It has economical importance for the region. Chemical composition and sensory attributes of Ezine cheeses (22 samples) collected from local producers were characterized (Karagul-Yuceer et al., 2007). A descriptive sensory evaluation technique was used to determine flavor profile. Major descriptive terms generated by panel members were FFA, cooked, creamy, whey-like, animal-like, salty, and sour. In general, Ezine cheese is ripened in tinplate containers $(17-20 \mathrm{~kg}$ capacity). However, at the end of the ripening period, cheeses can be repacked in smaller packages, such as tinplate or plastic vacuum packaging, for retail purposes.

Characteristic aroma-active compounds and effects of packaging type and size on some properties of Ezine cheese were not determined. The objectives of this study were to determine and compare the changes in basic composition, aroma and sensory characteristics, and proteolytic activity of Ezine cheese stored in tinplate containers and plastic vacuum packages over 12 mo.

\section{MATERIALS AND METHODS}

\section{Cheese Making Procedure}

Cheese was produced in a local cheese plant in May. The mixture of goat milk, sheep milk, and cow milk $(1,500-2,000 \mathrm{~L})$ was pasteurized at $67^{\circ} \mathrm{C}$ for $30 \mathrm{~min}$. After coagulation of milk by rennet enzyme at 32 to $34^{\circ} \mathrm{C}$, cheese gel was cut and whey was drained. Then, cheese curd was molded and immersed in brine (14-16\%). After that, cheese molds were put in tinplate containers (20 kg capacity) and brine was added. After finishing a 3 -mo ripening period in the tinplate container, cheeses were repacked in 1-kg plastic vacuum packaging or 1-kg tinplate containers. Three groups of cheeses (C: $20-\mathrm{kg}$ tinplate coated with lacquer, $\mathbf{T}$ : $1-\mathrm{kg}$ tinplate coated with lacquer, and V: 1-kg plastic vacuum pack) were analyzed in every 3-mo period. Duplicate cheese samples were used for each period. Cheeses were ripened at 2 to $4^{\circ} \mathrm{C}$ for $12 \mathrm{mo}$.

\section{Composition of Cheese}

Procedures described by Bradley et al. (1992) were followed to determine titratable acidity (lactic acid, \%), $\mathrm{pH}$, dry matter (\%), total protein (\%), salt (\%), and ash $(\%)$ in the cheeses. Fat content was determined by the Gerber-van Gulik method (NEN 3059, 1969).

\section{Analysis of Aroma Compounds}

Aroma compounds (Tables 2 and 3) were provided by Aldrich Chemical Co. (St. Louis, MO), Bedoukian Research Inc. (Danbury, CT), Merck (Darmstadt, Germany), Fluka (Seelze, Germany), and Aromsa (Gebze, Kocaeli, Turkey).

\section{Sample Preparation}

Thermal Extraction. To isolate aroma compounds in cheese, a thermal extractor (TE 2, Gerstel GmbH and Co. KG, Mülheim an der Ruhr, Germany) was used. Three grams of cheese, homogeneously prepared, was put in a glass extraction tube and aroma compounds were purged under an ultra-pure nitrogen gas stream at constant flow on Tenax TA (Gerstel GmbH and Co. KG) absorbent. Tenax TA is a porous material and it contains approximately $60 \mathrm{~mm}$ or $180 \mathrm{mg}$ of 2,6-diphenylene oxide polymer. The thermal extraction process was applied at $30^{\circ} \mathrm{C}$ for 15 min by using a heater (Aux Controller 163, Gerstel GmbH and Co. KG).

Thermal Desorption. Volatiles adsorbed on the Tenax TA were thermally desorbed (TDS 2, Gerstel $\mathrm{GmbH}$ and Co. KG) and cryo-focused at $-150^{\circ} \mathrm{C}$ before injection (Cooled Injection System CIS, Gerstel $\mathrm{GmbH}$ and Co. KG) to perform gas chromatographyolfactometry (GCO) analysis. A similar extraction and desorption procedure was used for the characterization of nutty flavor in Cheddar cheese (Avsar et al., 2004).

\section{GCO}

The GCO system consisted of an HP 6890 GC (Agilent Technologies, Wilmington, DE) equipped with a flame-ionization detector (FID), a sniffing port, and cooled injection system (CIS). Helium was used as a carrier gas. Inlet pressure was 20 psi and total flow was $25.1 \mathrm{~mL} / \mathrm{min}$. A polar capillary column (HP-Innowax $30 \mathrm{~m}$ length $\times 0.25 \mathrm{~mm}$ i.d. $\times 0.25 \mu \mathrm{m}$ film thickness; J\&W Scientific, Folsom, CA) and a nonpolar column (HP-5 $30 \mathrm{~m}$ length $\times 0.32 \mathrm{~mm}$ i.d. $\times 0.25 \mu \mathrm{m}$ film thickness; J\&W Scientific) were used for sniffing. After the analytical column, effluent was split 1:1 between the FID and olfactory port using deactivated fused 
silica capillaries $(90 \mathrm{~cm}$ length $\times 0.25 \mathrm{~mm}$ i.d.). Oven temperature was programmed from 30 to $240^{\circ} \mathrm{C}$ at a rate of $10^{\circ} \mathrm{C} / \mathrm{min}$, with initial and final hold times of 3 and $20 \mathrm{~min}$, respectively. The FID and sniffing port were maintained at the temperatures of $320^{\circ} \mathrm{C}$ and $200^{\circ} \mathrm{C}$, respectively. The CIS was programmed from -150 to $280^{\circ} \mathrm{C}$ at a rate of $12^{\circ} \mathrm{C} / \mathrm{s}$. Final hold time was 3 min. Equilibrium time was 0.05 min. Postpeak intensity scale was used for determination of aroma intensity. Two sniffers quantified the odor intensities using a 10-point scale anchored on the left with "not" and on the right with "very." Odorants were identified by comparing retention indices and odor quality of unknowns with those of authentic standards analyzed at the same experimental conditions. Retention indices were calculated by using n-alkane series (Van den Dool and Kratz, 1963). Sniffers had $80 \mathrm{~h}$ of experience with GCO technique, scale using, and odor description.

\section{Sensory Analysis}

A roundtable discussion with a 9-member panel (4 females and 5 males, ages ranged from 24 to 39 yr) was conducted to identify the descriptive flavor terms for the cheeses (Meilgaard et al., 1999). Panelists were introduced to the flavor terms developed by KaragulYuceer et al. (2007) for Ezine cheese. The same descriptive terms were used by the panel members. Sensory evaluation was started in the third month of storage and samples were evaluated every 3 mo over the 12 mo storage period. Panelists quantified the attributes using 15-point product-specific scales anchored on the left with "not" and on the right with "very" (Meilgaard et al., 1999). The panel received about $50 \mathrm{~h}$ of training during generation and definition of descriptive terms. Panelists were presented with water, unsalted crackers, and expectoration cups to cleanse the palate between samples. Cheeses were presented in 3-digit-coded styrofoam plates. Duplicate samples were served in the different sessions. All panelists in a session evaluated the same cheeses in a randomized order.

\section{Electrophoretic Analysis}

Sample Preparation. A homogeneous sample (0.5 g) was transferred into a 50-mL Falcon tube. Ether was used to extract the fat from the cheese. Sample buffer was prepared by mixing $7.5 \mathrm{~g}$ of Tris, $490 \mathrm{~g}$ of urea, and $4 \mathrm{~mL}$ of $\mathrm{HCl}$ acid $(37.5 \%)$ and made up to $1 \mathrm{~L}$ with distilled water. The 0.5 -g sample was dissolved in 25 $\mathrm{mL}$ of buffer. After mixing, the sample was kept in a $55^{\circ} \mathrm{C}$ waterbath for $10 \mathrm{~min}$, and then it was centrifuged at $3,000 \times g$ at $10^{\circ} \mathrm{C}$ for $10 \mathrm{~min}$ (Sigma, Gottingen, Germany).

The central portion $(2 \mathrm{~mL})$ was transferred into a $15-\mathrm{mL}$ centrifuge tube, $60 \mu \mathrm{L}$ of 2-mercaptoethanol and $40 \mu \mathrm{L}$ of bromphenol blue $(0.1 \%)$ were added, and then mixed. Casein standards $(\beta$, bovine milk, min. $90 \%$; and $\alpha$, bovine milk, min. 70\%; Sigma-Aldrich) were dissolved in sample buffer. Samples and standards were applied into gel with a $10-\mu \mathrm{L}$ syringe (Hamilton, Bonaduz, Switzerland).

Urea PAGE Analysis. The procedure for urea PAGE of casein samples was similar to the method reported by Andrews (1983) with some modification. The assays were carried out with a Protean LI XI vertical slab unit and a Powerpac Basic power supply (Bio-Rad Laboratories Ltd., Watford, UK).

The slab gels consisted of a $4 \%$ stacking gel and a $12 \%$ separating gel. Separating gel buffer was prepared by dissolving $3.2 \mathrm{~g}$ of Tris and $19.3 \mathrm{~g}$ of urea in 100 $\mathrm{mL}$ of distilled water, and then the $\mathrm{pH}$ was adjusted to 8.8 with $0.1 \mathrm{~N} \mathrm{HCl}$ using a $\mathrm{pH}$ meter. The solution was made up to $50 \mathrm{~mL}$ with distilled water. Then, 3.75 $\mathrm{mL}$ of $40 \%$ acrylamide/bisacrylamide (37.5/1) solution, $8.75 \mathrm{~mL}$ of separating buffer, $6 \mu \mathrm{L}$ of tetramethylethylenediamine, and $25 \mu \mathrm{L}$ of ammonium persulfate solution (10\% wt/vol) was transferred into an Erlenmeyer flask, shaken, and immediately poured into the gel apparatus. Distilled water $(0.5-1 \mathrm{~mL})$ was placed on the gel solution for a uniform surface. After polymerization, water was removed by drying paper.

Stacking gel buffer was prepared by dissolving 0.41 $\mathrm{g}$ of Tris and $15 \mathrm{~g}$ of urea in $100 \mathrm{~mL}$ distilled water, and then the $\mathrm{pH}$ was adjusted to 8.4. The solution was made up to $50 \mathrm{~mL}$. Then, $0.5 \mathrm{~mL}$ of $40 \%$ acrylamide/ bisacrylamide (37.5/1) solution, $4.5 \mathrm{~mL}$ of stacking gel buffer, $5 \mu \mathrm{L}$ of tetramethylethylenediamine, and $20 \mu \mathrm{L}$ of ammonium persulfate were added. After shaking, this solution was poured on the separating gel. After polymerization, the comb was removed.

Electrophoresis running buffer was prepared by dissolving $3 \mathrm{~g}$ of Tris and $14.6 \mathrm{~g}$ of glycine in 1,000 $\mathrm{mL}$ of distilled water, then the $\mathrm{pH}$ was adjusted to 8.4. Electrophoresis was performed at room temperature at 100 $\mathrm{V}$ until the end of the stacking gel. Then voltage was increased to $110 \mathrm{~V}$ until the tracking dye reached the bottom of the gel. The gel was stained with Coomassie Brilliant Blue R250 and dried with a gel air drying system (Bio-Rad Laboratories Ltd.). Image analysis was performed by PC scanner (HP Scanjet 2400, Agilent Technologies). Casein band density was determined by using a Gel-Pro Analyzer (Version 4, MediaCybernetics, Bethesda, MD). 


\section{Nitrogen Fractions}

Water-Soluble Nitrogen. Grated cheese samples $(10 \mathrm{~g})$ were mixed with $40 \mathrm{~mL}$ of distilled water and blended with an electric hand-held homogenizer (Biospec Products Inc., Bartlesville, OK) for 3 min. The mixture was held at $40^{\circ} \mathrm{C}$ for $1 \mathrm{~h}$ in a waterbath (ST-402, Nüve, Ankara, Turkey) and then centrifuged (Sigma 2-16K, Sigma Zentrifugen, Osterode am Harz, Germany) at $3,000 \times g$ for $30 \mathrm{~min}$ at $4^{\circ} \mathrm{C}$. The upper fat layer was removed and the supernatant filtered through Whatman \#42 filter paper (Kuchroo and Fox, 1982). Ten milliliters of filtrate was taken and the nitrogen content was determined by the micro-Kjeldahl method (IDF, 1993).

Trichloroacetic Acid Soluble Nitrogen (12\%). Trichloroacetic acid soluble nitrogen (TCASN) was prepared by mixing $25 \mathrm{~mL}$ of water-soluble extract with an equal amount of $24 \%$ trichloroacetic acid solution. The mixture was held at room temperature for 1 $\mathrm{h}$ and then filtered through Whatman \#42 filter paper (Polychroniadou et al., 1999). Twenty-five milliliters of filtrate was taken and the nitrogen content was determined by the micro-Kjeldahl method (IDF, 1993).

Phosphotungstic Acid Soluble Nitrogen (5\%). Phosphotungstic acid soluble nitrogen (PTASN) was prepared by mixing $5 \mathrm{~mL}$ of water-soluble extract with $3.5 \mathrm{~mL}$ of $3.95 \mathrm{M} \mathrm{H}_{2} \mathrm{SO}_{4}$ and $1.5 \mathrm{~mL}$ of $33.3 \%$ phosphotungstic acid solution. After the mixture was held overnight at $4^{\circ} \mathrm{C}$, it was filtered through Whatman \#42 filter paper (Jarrett et al., 1982). The nitrogen content of the filtrate was determined by the micro-Kjeldahl method (IDF, 1993).

\section{Statistical Analysis}

The effect of storage periods and packaging materials on sensory descriptors and nitrogen fractions of the cheeses were analyzed by factorial ANOVA model [1]. Tukey's HSD multiple comparison test was used for mean separations:

$$
\mathrm{Y}_{\mathrm{ijk}}=\mu+\mathrm{S}_{\mathrm{i}}+\mathrm{P}_{\mathrm{j}}+(\mathrm{SP})_{\mathrm{ij}}+\mathrm{e}_{\mathrm{ijk}},
$$

where $Y_{\mathrm{ijk}}$ is the observed or measured value of the cheese $\mathrm{k}$ in storage $\mathrm{i}$ and packaging $\mathrm{j}, \mu$ is the general population mean, $S_{i}$ is the effect of storage periods ( $\mathrm{i}$ $=1,2,3,4), \mathrm{P}_{\mathrm{j}}$ is the effect of packaging materials $(\mathrm{j}$ $=1,2,3),(\mathrm{SP})_{\mathrm{ij}}$ is the effect of storage by packaging interaction, and $\mathrm{e}_{\mathrm{ijk}}$ is the random error term.

The nonmetric multidimensional scaling method was used to investigate the relations between some sensory and aroma characteristics. Multidimensional scaling is a technique for finding a configuration of points in low-dimensional space that represents multivariate data. Essentially, the purpose of multidimensional scaling is to provide a visual representation of the pattern of proximities (i.e., similarities or distances) among a set of objects (Kruskal, 1964; Karagul-Yuceer et al., 2007). Stress coefficient and $\mathrm{R}^{2}$ were used to determine goodness-of-fit. All statistical analyses were performed using SPSS for Windows (version 15.0; SPSS, 2006).

\section{RESULTS AND DISCUSSION}

\section{Composition of Cheese}

There were no significant differences among the cheeses in terms of dry matter content (\%) during the 12-mo storage period $(P>0.05)$. However, packaging type significantly changed the dry matter $(P=0.025)$. The highest dry matter content was observed in sample $\mathrm{C}$ $(48.76 \%)$ and the lowest one was in sample V (47.13\%). This might be related to the packaging material and size. A significant interaction was determined between packaging material and storage $(P=0.016)$ in terms of salt content. Salt content of the cheeses ranged between 2.99 and $3.92 \%$. No significant differences were observed in cheeses $\mathrm{T}$ and $\mathrm{V}$ during storage. However, sample $\mathrm{C}$ had the lowest salt content (2.99\%) at the third month. In addition, no significant differences among the cheeses were observed after 3 mo of storage.

Table 1 shows the changes in lactic acid (\%), pH, fat (\%), and ash (\%) contents of the cheeses over 12 mo. Acidity of cheeses in mo 9 to 12 was higher than the values at mo 3 and 6 . No significant differences were observed in the fat contents of the cheeses during storage (Table 1). The highest ash content was observed at 12 mo (Table 1). Ezine cheeses were in the normal ranges in terms of acidity and composition (TS 591, 1995). These results were supported by the findings of Hayaloglu et al. (2005) for Turkish White brined cheese.

\section{Aroma-Active Compounds and Sensory Evaluation}

In total, 35 aroma-active compounds were identified in Ezine cheese during 12 mo of storage (Tables 2 and 3 ). These compounds belonged to different chemical families including aldehydes, ketones, esters, acids, sulfur compounds, and alcohol. Table 2 shows the aromaactive compounds, odor properties, and aroma intensities of the compounds determined in cheese samples before packaging on the first day of cheese production. Aroma intensities of cheeses stored in different packaging materials over 12 mo of storage can be seen in Table 3. Only 3 different odorants were identified in the cheese samples before packaging (Table 2). These 
Table 1. Lactic acid, $\mathrm{pH}$, fat, and ash during 12 mo of storage

\begin{tabular}{lcccc}
\hline & \multicolumn{4}{c}{ Composition/property $($ mean \pm SE) } \\
\cline { 2 - 5 } Month & Lactic acid $(\%)$ & $\mathrm{pH}$ & Fat $(\%)$ & Ash $(\%)$ \\
\hline 3 & $0.67 \pm 0.04^{\mathrm{b}}$ & $5.52 \pm 0.02^{\mathrm{b}}$ & $24.67 \pm 0.35^{\mathrm{a}}$ & $4.91 \pm 0.05^{\mathrm{b}}$ \\
6 & $0.62 \pm 0.03^{\mathrm{b}}$ & $5.72 \pm 0.02^{\mathrm{a}}$ & $24.75 \pm 0.93^{\mathrm{a}}$ & $4.97 \pm 0.05^{\mathrm{b}}$ \\
9 & $0.86 \pm 0.02^{\mathrm{a}}$ & $5.18 \pm 0.01^{\mathrm{c}}$ & $24.83 \pm 0.12^{\mathrm{a}}$ & $5.09 \pm 0.04^{\mathrm{ab}}$ \\
12 & $0.90 \pm 0.02^{\mathrm{a}}$ & $5.13 \pm 0.02^{\mathrm{c}}$ & $23.96 \pm 0.20^{\mathrm{a}}$ & $5.22 \pm 0.05^{\mathrm{a}}$ \\
$P$-value & 0.000 & 0.000 & 0.043 & 0.010 \\
\hline
\end{tabular}

${ }^{\mathrm{a}-\mathrm{c}}$ Means in the same column followed by different superscript letters represent significant differences.

odorants were propionic acid, (E,E)-2,4 decadienal, and $\beta$-ionene. These chemicals were not identified in aged cheeses. In general, intensities of aroma compounds for first day cheese (Table 2) were lower than samples stored in different packaging material for 12 mo (Table 3). Specifically, dimethyl sulfide with sulfur/corn-like aroma note, diacetyl with buttery note, and ethyl butyrate with bubble gum odor quality had very high aroma intensity on d 1 (Table 2).
Intensity of diacetyl was very high in the fresh cheese (Table 2). Probably, diacetyl was produced by the activity of nonstarter lactic acid bacteria in fresh cheese. However, lower odor intensities were observed in cheeses $\mathrm{C}, \mathrm{T}$, and $\mathrm{V}$ during storage (Table 3 ). High salt content and low $\mathrm{pH}$ values of cheeses during storage may inhibit the bacterial growth. Urbach (1997) showed that diacetyl was responsible for a mild and pleasant flavor of young Cheddar cheese. Utilization of citrate by lactic

Table 2. Aroma-active compounds in Ezine cheese by postpeak intensity (10-point scale) on d 1

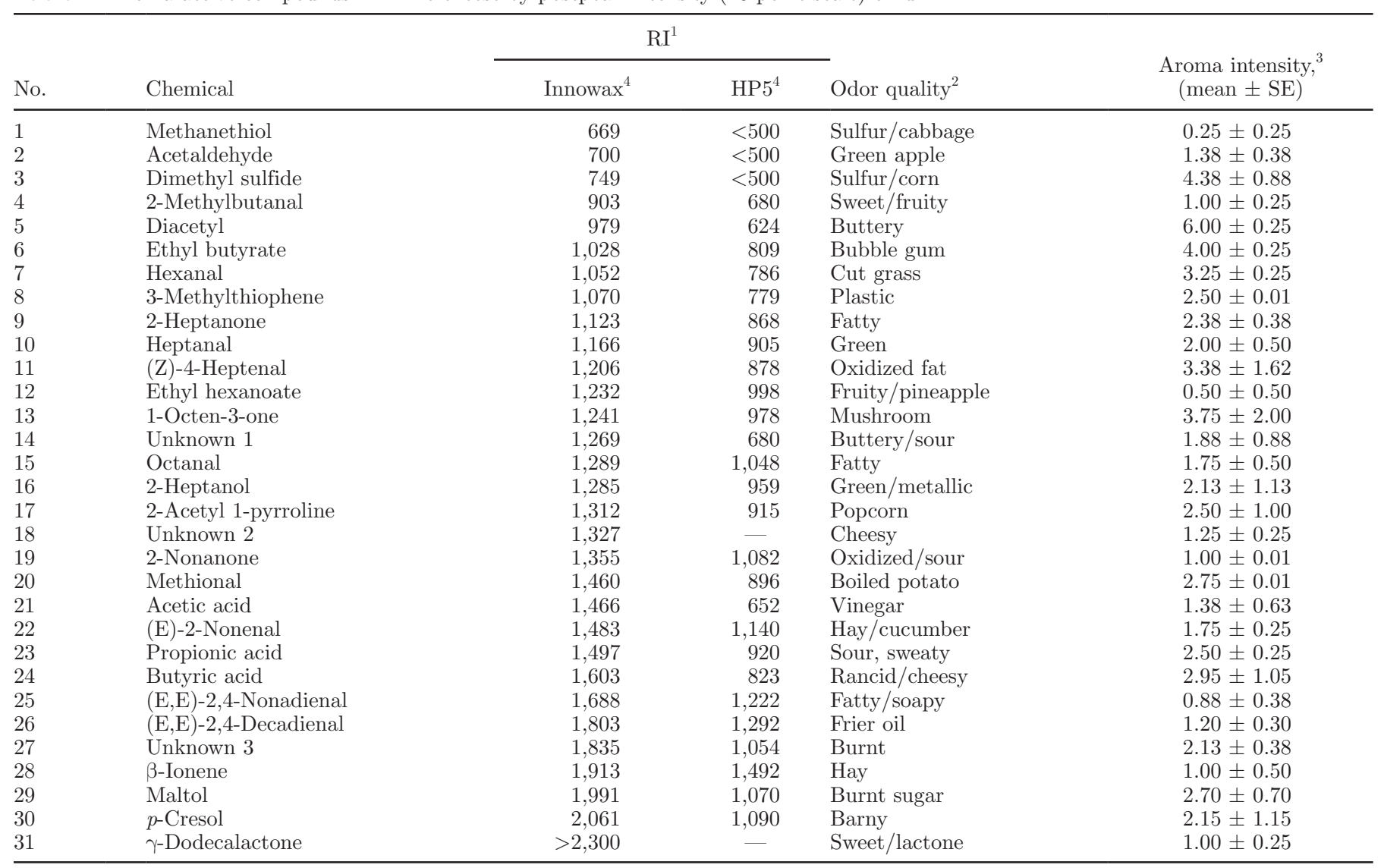

${ }^{1}$ Retention indices on Innowax and HP5 colunms.

${ }^{2}$ Aroma quality determined on olfactory port.

${ }^{3}$ Mean aroma intensities (postpeak intensity, 10-point scale) given by 2 sniffers on Innowax column. Odor intensities represent the mean of each sample evaluated in duplicate by 2 sniffers.

${ }^{4} \mathrm{~J} \& W$ Scientific, Folsom, CA. 
Table 3. Aroma-active compounds in Ezine cheeses stored in tinplate container and plastic vacuum over 12 mo of storage by postpeak intensity (10-point scale)

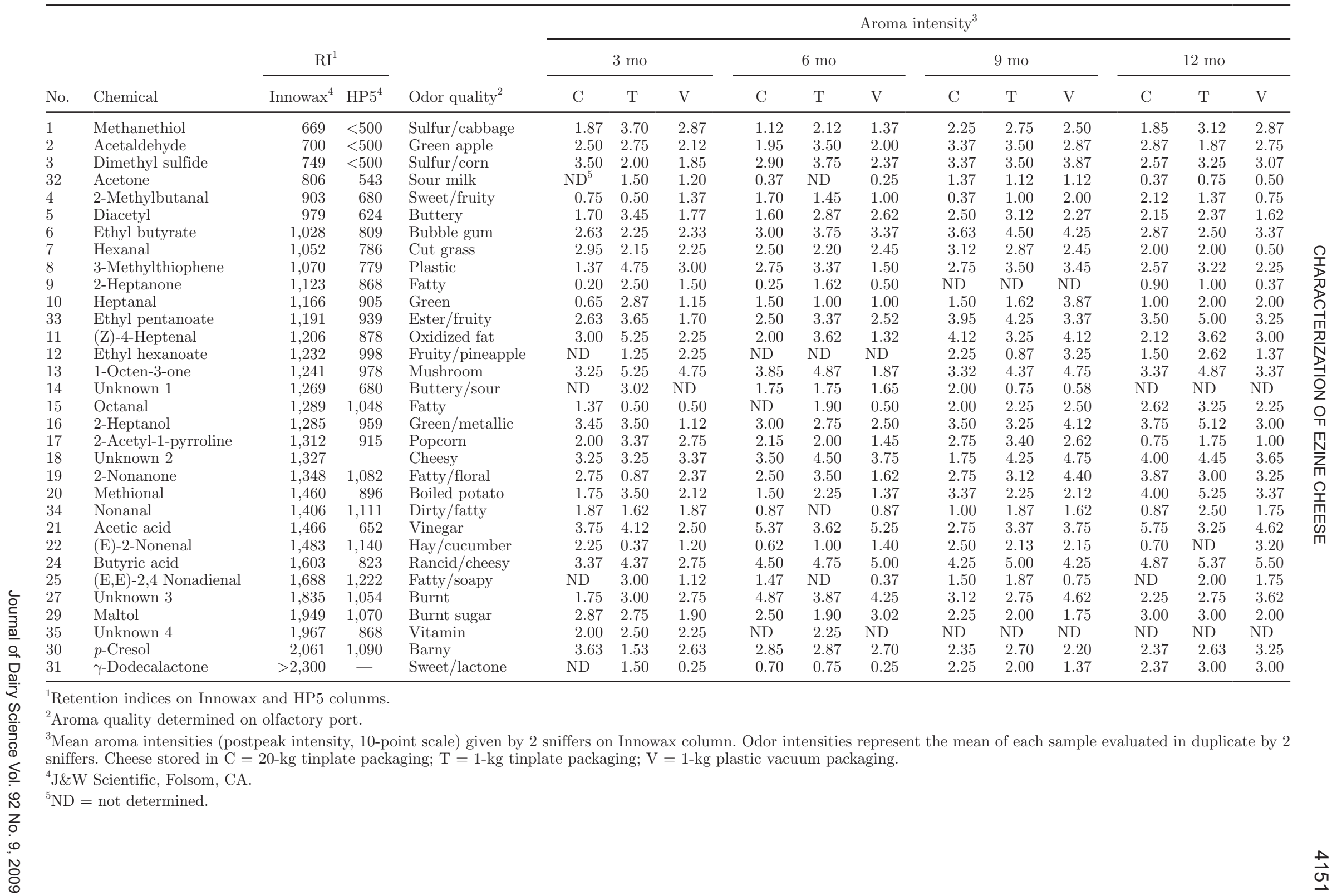


Table 4. Sensory attributes of Ezine cheese over 12 mo of storage ${ }^{1}$

\begin{tabular}{|c|c|c|c|c|c|c|c|c|c|c|}
\hline Month & \multicolumn{10}{|c|}{ Mean intensity of sensory attributes } \\
\hline 3 & $2.42^{\mathrm{a}}$ & $2.01^{\mathrm{a}}$ & $1.95^{\mathrm{b}}$ & $0.75^{\mathrm{d}}$ & $1.17^{\mathrm{b}}$ & $1.22^{\mathrm{c}}$ & $1.31^{\mathrm{c}}$ & $2.14^{\mathrm{b}}$ & $8.80^{\mathrm{b}}$ & $0.57^{\mathrm{b}}$ \\
\hline 9 & $2.00^{\mathrm{b}}$ & $1.51^{\mathrm{c}}$ & $2.00^{\mathrm{b}}$ & $1.00^{\mathrm{c}}$ & $1.33^{\mathrm{b}}$ & $1.44^{\mathrm{b}}$ & $1.58^{\mathrm{b}}$ & $2.18^{\mathrm{b}}$ & $10.47^{\mathrm{a}}$ & $1.14^{\mathrm{a}}$ \\
\hline 12 & $2.14^{\mathrm{ab}}$ & $1.73^{\mathrm{b}}$ & $2.18^{\mathrm{b}}$ & $1.58^{\mathrm{b}}$ & $1.78^{\mathrm{a}}$ & $1.61^{\mathrm{b}}$ & $1.77^{\mathrm{ab}}$ & $2.65^{\mathrm{b}}$ & $9.99^{\mathrm{a}}$ & $1.18^{\mathrm{a}}$ \\
\hline$P$-value & 0.002 & 0.000 & 0.000 & 0.000 & 0.000 & 0.000 & 0.000 & 0.000 & 0.000 & 0.000 \\
\hline
\end{tabular}

${ }^{\mathrm{a}-\mathrm{d}}$ Means in the same column followed by different superscript letters represent significant differences.

${ }^{1}$ Attributes were scored on a 15 -point universal Spectrum intensity scale where $0=$ absence of the attribute and $15=$ extremely high intensity of the attribute (Meilgaard et al., 1999).

acid bacteria plays a key role in generation of diacetyl, which is an important flavor compound of butter, buttermilk, and some young cheeses (Starrenburg and Hugenholtz, 1991).

Sulfur-containing compounds including methanethiol, dimethyl sulfide, and methional were identified in Ezine cheese samples. Intensities of methanethiol and methional increased in samples during storage. Specifically, samples $\mathrm{C}$ and $\mathrm{T}$ had the highest methional intensities at the mo 12 of storage (Table 3). Methional is the first product of Strecker degradation of methionine (Ballance, 1961; Tressl et al., 1989). Methanethiol and dimethyl sulfide were major contributors of Cheddar cheese flavor (Milo and Reineccius, 1997) and Swiss Gruyere cheese flavor (Rychlik and Bosset, 2001).

Heat-generated aroma-active compounds were also identified in Ezine cheeses. These volatiles were maltol, diacetyl, and 2-acetyl-1-pyrroline (Tables 2 and 3). Scanlan et al. (1968) also identified diacetyl and maltol as heat-generated aroma compounds in milk. On d 1, maltol intensity was 2.70 (Table 2). Maltol intensities of cheeses were between 1.75 and 3.02 during storage (Table 3). However, the intensity of 2-acetyl-1-pyrroline with popcorn-like aroma note was 2.5 in cheese on $\mathrm{d} 1$ (Table 2). At the end of storage (mo 12), C, T, and V samples had lower intensities of popcorn aroma than in other months (Table 3).

Some other compounds with high intensities were hexanal, (Z)-4-heptenal, 1-octen-3-one, and butyric acid in Ezine cheese on d 1 (Table 2). Hexanal with cut grass aroma was an important contributor of Ezine cheese aroma. Odor intensity was higher for $\mathrm{d} 1$ cheese (Table 2) than for other cheeses during storage (Table 3). Hexanal is a secondary oxidation product of linoleic acid (Hammond and Hill, 1964). Hexanal was also identified in other pickled cheeses including Teleme (Massouras et al., 2006) and Feta (Bintsis and Robinson, 2004). Mushroom-like aroma was generated by 1-octen-3-one in Ezine cheeses at high intensities (Tables 2,3 ). The intensity of this aroma varied in cheeses stored in different packaging material during storage. In general, sample $\mathrm{T}$ had higher intensities of mushroom odor than samples $\mathrm{C}$ and $\mathrm{V}$ over the 12 -mo storage period. Certain oxidation conditions may generate mushroom flavors; 1-octen-3-one was identified as being responsible for mushroom flavor in skim milk and butterfat (Stark and Forss, 1964) and skim milk powder (Karagul-Yuceer et al., 2001).

Garde et al. (2005) determined aroma compounds in Hispanico cheese, produced with and without bacteriocin-producing lactic culture, by using the dynamic headspace technique connected to GC-MS. They identified wide varieties of aroma compounds in the cheese including acetaldehyde, hexanal, heptanal, nonanal, ethyl butyrate, ethyl hexanoate, acetone, 2-heptanone, and 2-nonanone. We identified the same compounds in Ezine cheese.

Bintsis and Robinson (2004) investigated the effects of adjunct cultures on the aroma compounds of Fetatype cheese. Aroma compounds of the cheese samples were identified using headspace trapping onto Tenax TA and analyzed using thermal desorption combined with GC-MS. The flavor compounds isolated were alcohols, aldehydes, ketones, esters, and other miscellaneous compounds. The use of different adjunct cultures had a major effect on the volatile composition of cheese samples. High amounts of ethanol were identified in the cheeses. Acetaldehyde, hexanal, heptanal, octanal, and nonanal were some of the aldehydes in Feta cheeses. In addition, acetone, diacetyl, 2-heptanone, and 2-nonanone were major ketones of Feta cheese. Even though starter culture was not used in Ezine cheese, the same aldehydes and ketones were identified in this cheese, too.

Halloumi cheese is also ripened in brine (about $10 \%$ $\mathrm{NaCl}$ ). Kaminarides et al. (2007) investigated the changes in aroma compounds and sensory characteristics of Halloumi cheese kept in brine for $45 \mathrm{~d}$. For isolation of volatiles, the static headspace system was used. Acetaldehyde, acetone, diacetyl, acetic acid, and 
Table 5. Goaty and animal-like flavor intensities ${ }^{1}$ of Ezine cheeses stored in different packaging material

\begin{tabular}{lcc}
\hline & \multicolumn{2}{c}{ Mean intensity of sensory attributes } \\
\cline { 2 - 3 } Package $^{2}$ & Goaty & Animal-like \\
\hline $\mathrm{C}$ & $1.51^{\mathrm{ab}}$ & $1.66^{\mathrm{a}}$ \\
$\mathrm{T}$ & $1.38^{\mathrm{b}}$ & $1.47^{\mathrm{b}}$ \\
$\mathrm{V}$ & $1.59^{\mathrm{a}}$ & $1.54^{\mathrm{ab}}$ \\
$P$-value & 0.017 & 0.011 \\
\hline
\end{tabular}

${ }^{\mathrm{a}, \mathrm{b}}$ Means in the same column followed by different superscript letters represent significant differences.

${ }^{1}$ Attributes were scored on a 15-point universal Spectrum intensity scale where $0=$ absence of the attribute and $15=$ extremely high intensity of the attribute (Meilgaard et al., 1999).

${ }^{2}$ Cheese stored in $\mathrm{C}=20-\mathrm{kg}$ tinplate packaging, $\mathrm{T}=1-\mathrm{kg}$ tinplate packaging, $\mathrm{V}=1-\mathrm{kg}$ plastic vacuum packaging.

butyric acid were some of the volatiles determined at high intensities in the cheese during storage. These results agreed with our findings for Ezine cheese.

The results of sensory analysis were presented in Tables 4, 5, and 6. Significant differences were observed among the intensities of some descriptors over storage. Specifically, young cheese flavors including cooked and whey had higher intensities at mo 3 of storage. However, FFA, goaty, animal-like, and fermented scores were higher at mo 6 (Table 4). Basic taste scores such as sour, salty, and umami were lower at mo 3. Similar results were also found by Karagul-Yuceer et al. (2007) for Ezine cheeses that had different ripening periods.

Effect of packaging material was found significant on the intensities of goaty $(P=0.017)$ and animal-like flavor $(P=0.011)$ intensities (Table 5$)$. Goaty flavor score was higher in the cheese stored in plastic vacuum packaging $(\mathrm{V})$ than in 1-kg tinplate container ( $\mathrm{T}$; Table 5). Animal-like flavor of sample $\mathrm{C}$ was higher than that of sample T. Size and material of packaging might have an effect on flavor migration, permeation, or sorption (Risch, 2000).
Significant interactions were observed between packaging material and storage period for sulfur $(P=0.000)$, bitter $(P=0.000)$, sweet $(P=0.041)$, and bite $(P=$ 0.047 ) terms (Table 6 ). Sulfur aroma as an important descriptor for aged cheeses showed higher intensities for all C, T, and V samples after 6 mo of storage (Table 6). In general, sulfur intensities of samples $\mathrm{C}$ and $\mathrm{T}$ did not show significant differences. However, vacuum-packed cheeses at 6 and 12 months had lower sulfur intensities than the others (Table 6). Bitter, sweet, and bite intensities were also determined in the cheeses at very low intensities (Table 6). The main acidic compounds in Ezine cheese are acetic, butyric, and propionic acids (Tables 2 and 3). Acetic acid is produced by citrate and sugar metabolism in dairy foods (Cogan, 1995) or oxidative deamination of certain amino acids including glycine, alanine, and serine (Adda, 1982). It was shown that acetic acid characterizes pickled cheese with a harsh, but not rancid flavor (Abd El-Salam et al. 1993). The bite characteristic in cheeses may be related to this acidic compound. Butyric acid was also identified in other types of brined cheeses as a major volatile compound (Massouras et al., 2006; Kaminarides et al., 2007).

Figure 1 shows geometrical representation of sensory attributes and aroma-active compounds produced by multidimensional scaling. In general, statistically significant differences were not determined among the samples in terms of the attributes analyzed. Therefore, differences in packaging and time were disregarded. Visual representation of similarities of aromatic terms (taste terms not included) developed by sensory panelists and aroma-active compounds (intensity $>2$ ) of cheese samples can be seen in Figure 1. In this plot, variables that highly correlated are grouped together. For example, cooked flavor, 2-acetyl-1-pyrroline, diacetyl, 1-octen-3-one, 3-methylthiophene, and methanethiol grouped together (Figure 1). Goaty, animal-

Table 6. Sensory attributes ${ }^{1}$ of Ezine cheeses stored in different packaging material ${ }^{2}$ during 12 mo of storage

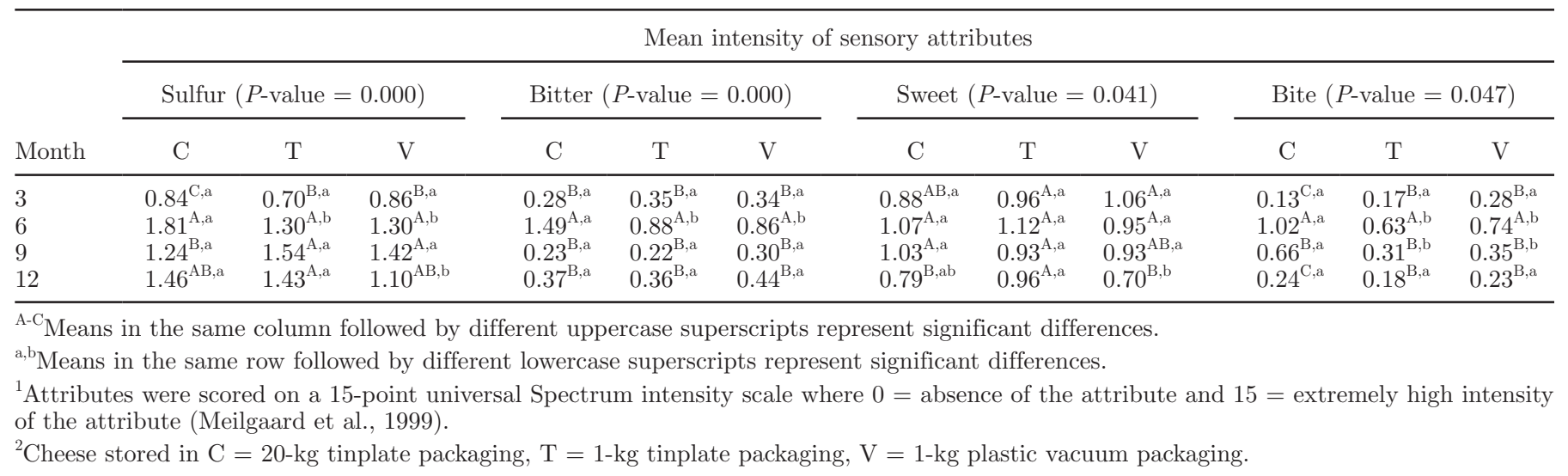




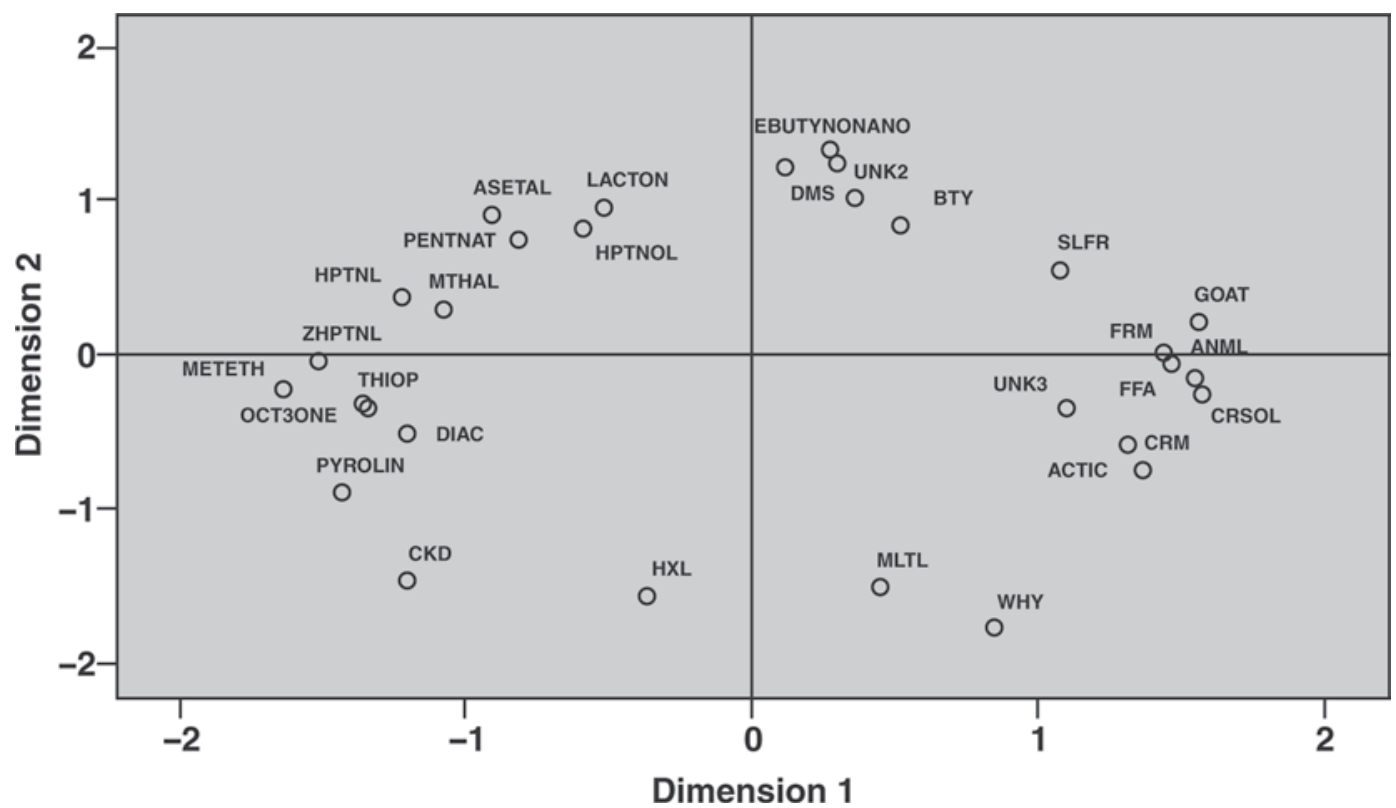

Figure 1. Geometrical representation of sensory attributes (only aromatics) and aroma-active compounds (intensity $>2$ ) produced by multidimensional scaling (stress $=0.643, \mathrm{R}^{2}=0.916$ ). $\mathrm{CKD}=$ cooked; WHY $=$ whey; $\mathrm{CRM}=$ creamy; FFA $=$ free fatty acid; GOAT $=$ goaty; ANML = animal-like; FRM = fermented; SLFR = sulfur; METETH = methanethiol; ASETAL = acetaldehyde; DMS = dimethyl sulfide; DIAC $=$ diacetyl; EBUTY = ethyl butyrate; HXL = hexanal; THIOP $=3$-methythiophene; HPTNL $=$ heptanal; PENTNAT $=$ ethyl pentanoate; ZHPTNL $=(\mathrm{Z})$-4-heptenal; OCT3ONE = 1-octen-3-one; HPTNOL = 2-heptanol; PYROLIN $=2$-acetyl-1-pyrroline; UNK2 = unknown 2; NONANO = 2-nonanone; MTHAL = methional; ACTIC = acetic acid; BTY = butyric acid; UNK3 = unknown 3; MLTL = maltol; CRSOL $=p$-cresol; LACTON $=\gamma$-dodecalactone.

like, fermented, and FFA descriptors developed by the sensory panel were closely related to $p$-cresol, which has a barny aroma note determined by GCO.

\section{Urea PAGE Analysis}

The effect of different packaging types on proteolysis is shown in Table 7 and Figure 2. It was observed that both $\beta$-casein and cow-origin $\alpha_{\mathrm{S}}$-casein slowly degraded and $88.7 \%$ of $\beta$-casein and $70.3 \%$ of $\alpha_{S}$-casein were not hydrolyzed by the end of 12 mo of ripening
(Table 7). Degradation of cow-origin $\alpha_{S}$-casein stopped between mo 6 and 9 and continued after mo 9 . However, degradation of sheep- and goat-origin $\alpha_{S}$ casein was notably faster than other caseins. Approximately half of $\alpha_{S}$-casein was hydrolyzed at the end of mo 6 . Degradation slowed in the following $3 \mathrm{mo}$ and $25.3 \%$ of $\alpha_{S}$-casein remained at the end of the storage period. Degradation of $\beta$-casein was observed to be similar in all cheeses in different packaging materials. Additionally, the degradation amount was 1 and $1.2 \%$ lower in $\mathrm{T}$ and $\mathrm{V}$, respectively, compared with $\mathrm{C}$. The lowest

Table 7. Residual $\beta$-casein and $\alpha_{\mathrm{s}}$-casein in Ezine cheeses during 12 mo of storage ${ }^{1}$

\begin{tabular}{|c|c|c|c|c|c|c|c|c|c|}
\hline \multirow[b]{3}{*}{ Month } & \multicolumn{9}{|c|}{ Casein types $^{2}(\%)$} \\
\hline & \multicolumn{3}{|c|}{$\beta$} & \multicolumn{3}{|c|}{$\alpha_{S^{-}}$Cow } & \multicolumn{3}{|c|}{$\alpha_{S}$-Ewe-goat } \\
\hline & $\mathrm{C}$ & $\mathrm{T}$ & $\mathrm{V}$ & $\mathrm{C}$ & $\mathrm{T}$ & $\mathrm{V}$ & $\mathrm{C}$ & $\mathrm{T}$ & $\mathrm{V}$ \\
\hline $0^{3}$ & 100 & 100 & 100 & 100 & 100 & 100 & 100 & 100 & 100 \\
\hline 3 & 94.6 & 94.6 & 94.6 & 93.3 & 93.3 & 93.3 & 80.2 & 80.2 & 80.2 \\
\hline 6 & 93.7 & 93.9 & 93.5 & 82.1 & 82 & 89.6 & 50.3 & 50.8 & 54.7 \\
\hline 9 & 92.4 & 92.8 & 91.8 & 82 & 75.9 & 88.3 & 29.4 & 26 & 88.3 \\
\hline 12 & 88.7 & 89.7 & 89.9 & 70.3 & 73.1 & 82.9 & 25.3 & 23.5 & 39.5 \\
\hline
\end{tabular}

${ }^{1}$ Cheese stored in $\mathrm{C}=20$-kg tinplate packaging; $\mathrm{T}=1$ - $\mathrm{kg}$ tinplate packaging; $\mathrm{V}=1$-kg plastic vacuum packaging.

${ }^{2} \alpha_{S^{-}}$Cow $=$cow-originated $\alpha_{S^{-}}$casein $; \alpha_{S^{-}}$Ewe-goat $=$sheep- and goat-originated $\alpha_{S^{-}}$casein .

${ }^{3}$ Month 0 represents the sample on $\mathrm{d} 1$. 


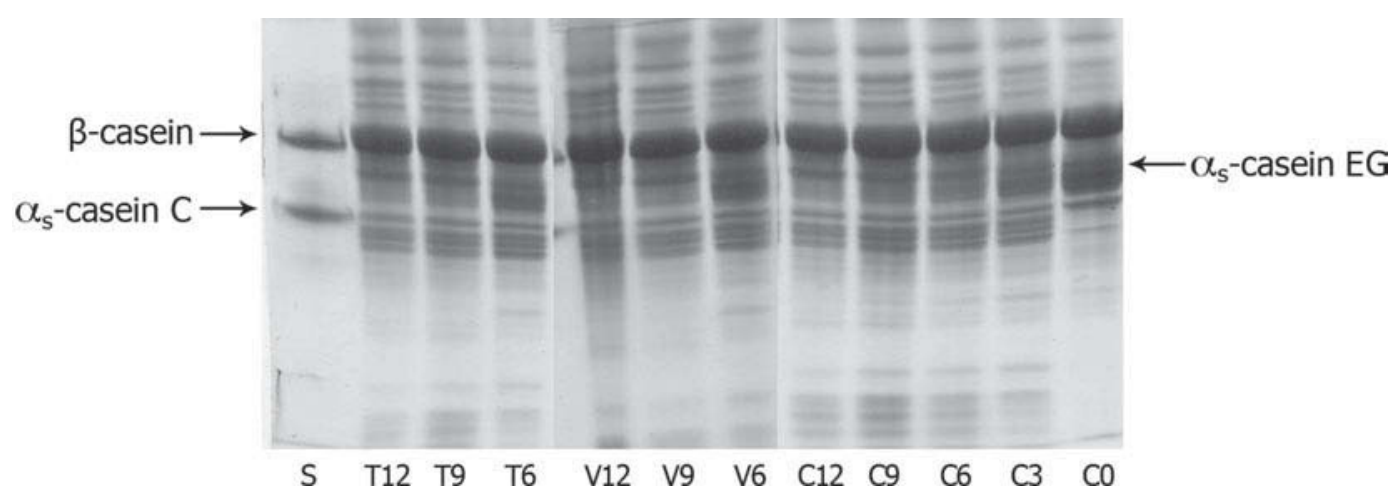

Figure 2. Urea-PAGE electrophoregram of the casein fractions of Ezine cheeses stored in different packaging types during 12 mo of storage. $\mathrm{S}=$ casein standards; $\alpha_{\mathrm{S}}$-casein $\mathrm{C}=\mathrm{cow}$ milk $\alpha_{\mathrm{S}}$-casein; $\alpha_{\mathrm{S}}$-casein $\mathrm{EG}=\alpha_{\mathrm{S}}$-casein sheep and goat milk; $\mathrm{C}=20$-kg tinplate packaging; $\mathrm{T}=1$-kg tinplate packaging; $\mathrm{V}=1-\mathrm{kg}$ plastic vacuum packaging; $\mathrm{C} 0=$ sample $\mathrm{C}$, first day; $\mathrm{C} 3=$ sample $\mathrm{C}$, mo $3 ; \mathrm{C} 6=$ sample $\mathrm{C}$, mo 6 ; $\mathrm{C} 9=$ sample $\mathrm{C}$, mo 9; C12 = sample $\mathrm{C}$, mo 12; V6 = sample V, mo 6; V9 = sample V, mo 9; V12= sample V, mo 12; T6 = sample T, mo 6; T9= sample $\mathrm{T}$, mo 9; $\mathrm{T} 12=$ sample $\mathrm{T}$, mo 12 .

degradation of cow-, sheep-, and goat-origin $\alpha_{S^{-}}$caseins was determined in sample V. Di Cagno et al. (2003) reported slight degradation of $\alpha_{S}$-casein and $\beta$-casein fragments in Canestrato Pugliese, Fiore Sardo, and Pecorino Romano cheeses made from sheep milk without adding starter culture in Italy. Slow hydrolysis of $\beta$-casein was shown in other brine-ripened cheeses (Saldamli and Kaytanli, 1998; Katsiari et al., 2000; Romeih et al., 2002). Hayaloglu et al. (2005) also found that cheese without starter had a slightly higher concentration of $\gamma$-caseins because of higher plasmin activity. In white pickled cheese, extensive plasmin activity is not expected because of the acidity and salt content (Michaelidou et al., 1998; Kandarikis et al., 2001).

Moatsou et al. (2002) investigated the level of proteolysis in Feta cheeses produced by using a mixture of sheep and goat milk (4:1) in 3 different dairy plants during 4 mo of storage. Yogurt was used as a starter culture. Urea PAGE analysis showed that $\alpha_{\mathrm{s}}$-casein degraded very quickly. However, $\beta$-casein breakdown was almost constant. The difference in amount of degradation was related to $\mathrm{pH}$ and salt-in-moisture contents of cheeses.

\section{Nitrogen Fractions}

Total nitrogen contents (\%) of cheeses were between 2.92 and 3.28 in the storage period. In general, there were no major changes in the total protein content of the cheeses. Tarakci and Tuncturk (2008) reported that the protein contents of white cheese were not changed during storage.

Changes in TCASN fraction of Ezine cheeses stored in different packaging material during 12 mo $(P=$ 0.027 ) are shown in Table 8. Trichloroacetic acid soluble nitrogen contains small peptides, free amino acids, ammonia, and other minor compounds produced by activity of bacterial enzymes (Kuchroo and Fox, 1982). Cinbas and Kilic (2006) pointed out that the TCASN fraction of white-brined cheese increased with storage time. In the present study, TCASN content of Ezine cheeses increased over the 12-mo storage period (Table 8). Sample $\mathrm{C}$ at mo 12 had a higher TCASN fraction than samples T and V (Table 8). Romeih et al. (2002) showed the increase in the level of TCASN in low-fat white-brined cheese during aging.

Table 9 showed the changes in water-soluble nitrogen (WSN, \%) and PTASN fractions during storage. The WSN fraction includes proteins, all peptides, amino acids, and $\mathrm{N}$ compounds produced mainly by the residual rennet activity and microbial enzymes (Lane and Fox, 1997; McSweeney and Fox, 1997; Thakur, 2006). The WSN fraction of the cheese increased significantly during ripening period ( $P=0.001$; Table 9$)$. Increase in levels of WSN during ripening was similar to the findings reported by Vassiliadis et al. (2009) for traditional

Table 8. Changes in trichloroacetic acid soluble nitrogen (TCASN) fraction of Ezine cheeses stored in different packaging material ${ }^{1}$ during 12 mo of storage

\begin{tabular}{lccc}
\hline & \multicolumn{3}{c}{ TCASN $\%$; mean $\pm \mathrm{SE})$} \\
\cline { 2 - 4 } Month & $\mathrm{C}$ & $\mathrm{T}$ & $\mathrm{V}$ \\
\hline 3 & $2.86 \pm 0.37^{\mathrm{C}, \mathrm{a}}$ & $3.83 \pm 0.09^{\mathrm{B}, \mathrm{a}}$ & $3.23 \pm 0.34^{\mathrm{C}, \mathrm{a}}$ \\
6 & $5.21 \pm 0.47^{\mathrm{B}, \mathrm{a}}$ & $5.63 \pm 0.46^{\mathrm{A}, \mathrm{a}}$ & $5.06 \pm 0.18^{\mathrm{B}, \mathrm{a}}$ \\
9 & $6.40 \pm 0.13^{\mathrm{B}, \mathrm{a}}$ & $6.43 \pm 0.06^{\mathrm{A}, \mathrm{a}}$ & $5.97 \pm 0.20^{\mathrm{A}, \mathrm{ab}}$ \\
12 & $8.83 \pm 0.80^{\mathrm{A}, \mathrm{a}}$ & $6.75 \pm 0.26^{\mathrm{A}, \mathrm{b}}$ & $7.36 \pm 0.04^{\mathrm{A}, \mathrm{b}}$ \\
\hline
\end{tabular}

$\overline{{ }^{A-C} \text { Means in the same column followed by different uppercase super- }}$ scripts represent significant differences $(P<0.05)$.

${ }^{\mathrm{a}, \mathrm{b}}$ Means in the same row followed by different lowercase superscripts represent significant differences $(P<0.05)$.

${ }^{1}$ Cheese stored in $\mathrm{C}=20$-kg tinplate packaging; $\mathrm{T}=1-\mathrm{kg}$ tinplate packaging; $\mathrm{V}=1-\mathrm{kg}$ plastic vacuum packaging. 
Table 9. Changes in water soluble nitrogen (WSN) and phosphotungstic acid soluble nitrogen (PTASN) fractions during 12 mo of storage

\begin{tabular}{lcc}
\hline Month & WSN $(\% ;$ mean \pm SE $)$ & PTASN $(\% ;$ mean \pm SE $)$ \\
\hline 3 & $7.52 \pm 0.35^{\mathrm{c}}$ & $1.55 \pm 0.12^{\mathrm{b}}$ \\
6 & $13.78 \pm 0.49^{\mathrm{b}}$ & $1.79 \pm 0.05^{\mathrm{b}}$ \\
9 & $15.21 \pm 1.01^{\mathrm{b}}$ & $2.43 \pm 0.18^{\mathrm{a}}$ \\
12 & $20.10 \pm 0.69^{\mathrm{a}}$ & $2.65 \pm 0.15^{\mathrm{a}}$ \\
\hline
\end{tabular}

${ }^{\mathrm{a}-\mathrm{c}}$ Means in the same column followed by different superscript letters represent significant differences $(P<0.01)$.

Greek Feta cheese. The PTASN fraction indicates very small peptides, amino acids, and $\mathrm{N}$ compounds (Thakur, 2006). The levels of PTASN increased significantly in all cheeses during storage $(P=0.000)$. Similar results were also obtained by Hayaloglu (2007) and Tarakci and Tuncturk (2008) for white-brined cheese.

The rates of increase in WSN, TCASN, and PTASN were faster, up to mo 6 of ripening. The changes in these nitrogen fractions after the 6 -mo aging period were slower than in the early aging periods (Tables 8 and 9). Low $\mathrm{pH}$ and high moisture contents in cheeses result in the activity of chymosin on $\alpha_{\mathrm{S} 1}$-casein, causing the rapid production of water-soluble peptides (Romeih et al., 2002).

\section{CONCLUSIONS}

For economic purposes, we recommend that Ezine cheese can be ripened in small-size packaging after $3 \mathrm{mo}$ of storage. Approximately $6 \mathrm{mo}$ is sufficient to develop the characteristic properties of Ezine cheese. Different groups of chemicals play an important role in the development of Ezine cheese aroma. The major aroma compounds are fatty acids, esters, sulfur compounds, and aldehydes. All types of cheeses contained approximately the same aroma-active compounds at different intensities. These differences may be results of packaging material/size and storage period. In general, no major differences were observed among the samples in terms of chemical and sensory properties of Ezine cheese during 12 mo of storage. The results clearly showed that the third month is the critical time for ripening. After the third month of storage, no major differences were found among the cheeses in terms of aroma-active compounds and sensory properties. Degradation of specifically $\alpha_{S}$-casein increased after 3 mo of storage. In addition, the levels of WSN, TCASN, and PTASN increased during storage.

\section{ACKNOWLEDGMENTS}

Funding was provided by the State Planning Organization. We thank the owner of Çamlıcalı Dairy Foods
Company, who generously provided cheese samples for this study. We also thank the panel members for their participation and input during panel training and product evaluation.

\section{REFERENCES}

Abd El-Salam, M. H., E. Alichanidis, and G. K. Zerfiridis. 1993. Domiati and Feta type cheeses. Pages 301-335 in Cheese: Chemistry, Physics and Microbiology. P. F. Fox, ed. Chapman and Hall, London, UK.

Adda, J. 1982. The chemistry of flavour and texture generation in cheese. Food Chem. 9:115-129.

Andrews, A. T. 1983. Proteinases in normal bovine milk and their action on caseins. J. Dairy Res. 50:45-55.

Avsar, Y. K., Y. Karagul-Yuceer, M. A. Drake, T. K. Singh, Y. Yoon, and K. R. Cadwallader. 2004. Characterization of nutty flavor in Cheddar cheese. J. Dairy Sci. 87:1999-2010.

Ballance, P. E. 1961. Production of volatile compounds related to the flavor of foods from the Strecker degradation of DL-methionine. J. Sci. Food Agric. 12:532-536.

Bintsis, T., and R. K. Robinson. 2004. A study of the effects of adjunct cultures on the aroma compounds of Feta-type cheese. Food Chem. 88:435-441.

Bradley, J. R. L., J. E. Arnold, D. M. Barbano, R. G. Semerad, D. E. Smith, and B. K. Vines. 1992. Chemical and physical methods. Pages 433-531 in Standard Methods for the Examination of Dairy Products. R.T. Marshall, ed. American Public Health Association, Washington, DC.

Cinbas, T., and M. Kilic. 2006. Proteolysis and lipolysis in White cheese manufactured by two different production methods. Int. J. Food Sci. Technol. 41:530-537.

Cogan, J. M. 1995. Flavour production by dairy starter cultures. J. Appl. Bacteriol. 79 (Symp. Suppl.):49-64.

Di Cagno, R., J. Banks, L. Sheehan, P. F. Fox, E. Y. Brechany, A. Corsetti, and M. Gobetti. 2003. Comparison of microbiological, compositional, biochemical, volatile profile and sensory characteristics of three Italian PDO ewes' milk cheeses. Int. Dairy J. 13:961-972.

Fox, P. F. 1989. Proteolysis during cheese manufacture and ripening. J. Dairy Sci. 72:1379-1400.

Fox, P. F., T. K. Singh, and P. L. H. McSweeney. 1995. Biogenesis of flavor compounds in cheese. Pages 59-98 in Chemistry of StructureFunction Relationships in Cheese. E. L. Malin and M. H. Tunick, ed. Plenum Press, New York, NY.

Garde, S. M., M. Avila, M. Medina, and M. Nunez. 2005. Influence of bacteriocin-producing lactic culture on the volatile compounds, odour and aroma of Hispanico cheese. Int. Dairy J. 15:10341043.

Hammond, E. G., and F. D. Hill. 1964. The oxidized metallic and grassy flavor components of autoxidized milk fat. J. Am. Oil Chem. Soc. 41:180-184.

Hayaloglu, A. A. 2007. Comparisons of different single-strain starter cultures for their effects on ripening and grading of Beyaz cheese. Int. J. Food Sci. Technol. 42:930-938.

Hayaloglu, A. A., M. Güven, P. F. Fox, and P. L. H. McSweeney. 2005. Influence of starters on chemical, biochemical, and sensory changes in Turkish White-Brined cheese during ripening. J. Dairy Sci. 88:3460-3474

IDF. 1993. Milk. Determination of the nitrogen (Kjeldahl method) and calculation of the crude protein content. IDF Standard 20B International Dairy Federation, Brussels, Belgium.

Jarrett, W. D., J. W. Aston, and J. R. Dulley. 1982. A simple method for estimating free amino acids in Cheddar cheese. Aust. J. Dairy Technol. 37:55-58.

Kaminarides, S., P. Stamou, and T. Massouras. 2007. Changes of organic acids, volatile aroma compounds and sensory characteristics of Halloumi cheese kept in brine. Food Chem. 200:219-225. 
Kandarikis, I. G., G. A. Moatsou, A. I. K. Georgola, S. Kaminarides, and E. Anifantakis. 2001. Effect of draining temperature on the biochemical characteristics of Feta cheese. Food Chem. 72:369378.

Karagul-Yuceer, Y., M. A. Drake, and K. R. Cadwallader. 2001. Aroma-active components of nonfat dry milk. J. Agric. Food Chem. 49:2948-2953.

Karagul-Yuceer, Y., M. Isleten, and C. Uysal-Pala. 2007. Sensory characteristics of Ezine cheese. J. Sens. Stud. 22:49-65.

Katsiari, M. C., E. Alichanidis, L. P. Voutsinas, and I. G. Roussis. 2000. Proteolysis in reduced sodium Feta cheese made by partial substitution of $\mathrm{NaCl}$ by KCl. Int. Dairy J. 10:635-646.

Kranenburg, R. V., M. Kleerebezem, J. V. H. Vlieg, B. M. Ursing, J. Boekhorst, B. A. Smit, E. H. E. Ayad, G. Smit, and R. J. Siezen. 2002. Flavor formation from amino acids by lactic acid bacteria: Predictions from genome sequence analysis. Int. Dairy J. 12:111-121

Kruskal, J. B. 1964. Multidimensional scaling by optimizing goodness of fit to a nonmetric hypothesis. Psychometrika 29:1-27.

Kuchroo, C. N., and P. F. Fox. 1982. Soluble nitrogen in Cheddar cheese: Comparison of extraction procedures. Milchwissenschaft 37:331-335.

Lane, C. N., and P. F. Fox. 1997. Role of starter enzymes during ripening of Cheddar cheese made form pasteurized milk under controlled microbiological conditions. Int. Dairy J. 7:55-63.

Law, B. A. 1984. Flavor development in cheese. Pages 187-208 in Advances in the Microbiology and Biochemistry of Cheese and Fermented Milk. F. L. Davies and B. A. Law, ed. Elsevier Applied Science, London, UK.

Massouras, T., E. C. Papa, and H. Mallatou. 2006. Headspace analysis of volatile flavour compounds of Teleme cheese made from sheep and goat milk. Int. J. Dairy Technol. 59:250-256.

McSweeney, P. L. H., and P. F. Fox. 1997. Chemical methods for the characterization of proteolysis in cheese during ripening. Lait $77: 41-76$

Meilgaard, M., G. V. Civille, and B. T. Carr. 1999. Descriptive analysis techniques. Pages 161-170 in Sensory Evaluation Techniques. 3rd ed. CRC Press, Boca Raton, FL.

Michaelidou, A., E. Alichanidis, H. Urlaub, A. Polychroniadou, and G. K. Zerfiridis. 1998. Isolation and identification of some major water-soluble peptides in Feta cheese. J. Dairy Sci. 81:31093116.

Milo, C., and G. A. Reineccius. 1997. Identification and quantification of potent odorants in regular-fat and low-fat mild Cheddar cheese. J. Agric. Food Chem. 45:3590-3594.

Moatsou, G., T. Massouras, I. Kandarakis, and E. Anifantakis. 2002. Evolution of proteolysis during the ripening of traditional Feta cheese. Lait 82:601-611.

NEN 3059 1969. Netherlands Standard. Butyrometric determination of the fat content of cheese (Gerber-van Gulik method). Neth. Milk and Dairy J. 23:214-220.

Ott, A., J. E. Germond, and A. Chaintreau. 2000. Origin of acetaldehyde during milk fermentation using ${ }^{13} \mathrm{C}$-labeled precursors. J. Agric. Food Chem. 48:1512-1517.

Polychroniadou, A., A. Michaelidou, and N. Paschaloudis. 1999. Effect of time, temperature and extraction method on trichloroacetic acid-soluble nitrogen of cheese. Int. Dairy J. 9:559-568.
Risch, S. J. 2000. Flavor and package interactions. Pages 94-100 in Flavor Chemistry. S. J. Risch, and C. T. Ho, ed. Industrial and Academic Research. ACS Symposium Series 756, American Chemical Society, Washington, DC.

Romeih, E. A., A. Michaelidou, C. G. Biliaderis, and G. K. Zerfiridis. 2002. Low-fat white brined cheese made from bovine milk and two commercial fat mimetics: Chemical, physical and sensory attributes. Int. Dairy J. 12:525-540.

Rychlik, M., and J. O. Bosset. 2001. Flavour and off-flavour compounds of Swiss Gruyere cheese. Evaluation of potent odorants. Int. Dairy J. 11:895-901.

Saldamli, I., and M. Kaytanli. 1998. Utilization of Fromase, Maxiren and Rennilase as alternative coagulating enzymes to rennet in Turkish White cheese. Milchwissenschaft 53:22-25.

Scanlan, R. A., L. M. Lindsay, L. M. Libbey, and E. A. Day. 1968. Heat-induced volatile compounds in milk. J. Dairy Sci. 51:10011007.

Singh, T. K., M. A. Drake, and K. R. Cadwallader. 2003. Flavor of Cheddar cheese: A chemical and sensory perspective. Compr. Rev. Food Sci. Food Saf. 2:139-162.

SPSS. 2006. SPSS Professional Statistics 15.0. SPSS Inc., Chicago, IL.

Stark, W., and D. A. Forss. 1964. A compound responsible for mushroom flavor in dairy products. J. Dairy Res. 31:253-259.

Starrenburg, M. J. C., and J. Hugenholtz. 1991. Citrate fermementation by Lactococcus and Leuconostoc spp. Appl. Environ. Microbiol. 57:3535-3540.

Tarakci, Z., and Y. Tuncturk. 2008. The effects of adjunct cultures on some chemical and biochemical properties of white-brined cheese. J. Food Biochem. 32:490-505.

Thakur, P. R. 2006. Effect of coagulants and calcium reduction on Mozzarella cheese functionality. MS Thesis. South Dakota State University, Brookings.

TPE. 2006. Cografi Isaret Tescil Belgesi, Türk Patent Enstitüsü, Yenimahalle, Ankara.

Tressl, R., B. Helak, N. Martin, and E. Kernsten. 1989. Formation of amino acid specific Maillard products and their contribution to thermally generated aromas. Pages 156-171 in Thermal Generation of Aromas. T. H. Parliament, R. J. McGorrin, and C. Ho, ed., ACS Symposium Series 409, American Chemical Society, Washington, DC

TS 591. 1995. Beyaz Peynir. Türk Standardları Enstitüsü. Necatibey Cad. 112, Bakanlıklar, Ankara, Türkiye.

Urbach, G. 1997. The flavour of milk and dairy products: II. Cheese: Contribution of volatile compounds. Int. J. Dairy Technol. 50:79 89 .

Van den Dool, H., and P. D. Kratz. 1963. A generalization of the retention index system including linear temperature programmed gas liquid partition chromatography. J. Chromatogr. A 11:463471 .

Vassiliadis, A., L. Psoni, S. Nikolaou, L. Arvanitis, N. Tzanetakis, and E. Elitopoulou-Tzanetaki. 2009. Changes in microbial populations, kinds of lactic acid bacteria and biochemical characteristics of Greek traditional Feta cheese during ripening. Int. J. Dairy Technol. 62:39-47. 